\title{
Mergawe: A Picture of Changing Women's Tradition
}

\author{
Moh. Faiz Maulana \\ Universitas Nahdlatul Ulama Indonesia, Jakarta - Indonesia \\ Email Penulis: faiz@unusia.ac.id
}

\section{Article Information}

$\begin{array}{llll}\text { Submitted } & : 2021-03-29 & \text { Revision } & : 2021-11-15 \\ \text { Reviewed } & : 2021-10-06 & \text { Published } & : 2021-11-30\end{array}$

\begin{abstract}
This research focuses on women's efforts in placing themselves in the right position. In the midst of changing times that are so fast and open, women are faced with a feeling of dilemma. On the one hand, women are limited by traditions that always place them in the domestic sphere, which is commonly known as konco wingking. On the other hand, changing times or modernization has given women the freedom to enter the public sphere. Through moderation of the tradition, women in Paciran have managed to get out of their dilemma. They can maintain their traditions and identity as Javanese women and can create new traditions by accepting them as workers. Tradition moderation has also changed the meaning and view of the konco wingking tradition, which so far has only been considered a "place of origin" with its domestic role; macak, masak, manak, but also a "place of return" the tradition that becomes the foothold of women's life in viewing social reality; community, and family. This research was conducted on women working nguplik in a village in Paciran, Lamongan, East Java. Nguplik is the job of separating the ripe crab shell or skin from the meat to be sold and processed into food and cosmetics. Nguplik is carried out by individuals and or a group of women. This study uses a qualitative method with a case study approach, with the data collection process using interviews and observations. To analyze the data we used the theory of cultural sociology. The finding of this research is the acceptance of women as workers.
\end{abstract}

Keywords: working women; nguplik; modernization; place of origin; place of return 


\section{Introduction}

Modernization presents a new image and role for Javanese women, which is positioned not only in the domestic sphere but also in the public sphere. Modernization gives freedom to women to choose their own space, whereas in previous values or traditions women were only positioned in the domestic space.

In Java, women are often positioned at home, known in Javanese terms as konco wingking, which means friends behind. Konco wingking is understood as a form of the role and duties of women who are behind. Konco wingking means that a woman's duty is only as a male friend (her husband) whose position is at home taking care of the household in the role of macak (make up), masak (cooking), manak (gift birth or take care of the family).

Konco Wingking explains the "place of origin" for women, where they were positioned in a society, then until now. The presence of konco wingking gives an understanding that the house is the identity of Javanese women. Apart from being a hereditary tradition, it is also considered natural for women. The nature of women is as a household manager, an obedient wife, and a mother who makes a complementary (Handayani \& Novianto, 2004; Permanadeli, 2015).

The entry of modernization has changed the image and role of women in society. Women can no longer be underestimated only in domestic matters. Modernization has changed the conception of konco wingking that has been attached to women's bodies for centuries. In the modern world, women can no longer be considered as objects that are placed in a special room called a house but must be seen as subjects who can choose their place.

Despite the fact, domestic activities are still not easily separated from the woman's body even though she has gone out to work. This is due in part to the socialization and internalization of patriarchal values, which have been going on for a long time. Apart from being carried out by the family, the socialization was also carried out by the community, and also by religious leaders. Geertz (1983: 153) in his study of Javanese families, revealed that in the process of socialization, individuals will recognize the demands of behaving by social norms prevailing in the society. Step by step he will adjust to the demands of life in the existing cultural environment. Thus the way of thinking and living habits of the individual will be formed. This socialization process has instilled values by the prevailing traditions in society. Also, according to Parson in Morgan (1975: 30-31) that the purpose of socialization, one of which is cultural inheritance. 
Therefore, the strong patriarchal values have made women in Paciran a dilemma. He is not free to do the work they are doing. They are limited by traditions and culture that place them as "home", which in particular creates a stigma and typology, for example macak, masak, manak on women's bodies. On the other hand, modernization has given women freedom of work.

Women in Paciran, for example, are not considered njawani, if they prefer to work rather than take care of the house. The loss of communal identity is caused by disobedience to existing values and traditions. Apart from that, it is also considered against the nature of women. Sukri and Sofwan (2001: 63) reveal that if there are women in a society who prefer to work rather than take care of the household, they are described as women who are considered to be against tradition and nature who cannot seek or create happiness for themselves and their families.

Permanadeli (2015: 292-293) states that even though modernization has provided space for women to work, it still makes it difficult or confused to determine suitable jobs. This can happen because the mental concept of working women cannot be separated from the tradition that predominantly places home as women domination, therefore the choice of the workplace is also very important. Women can enjoy full freedom over the opportunity to work during today's modern era, but many women still show boundaries and think that women must keep their traditions as konco wingking.

This makes women have to be able to do two things at once, be productive in the public sphere, and productive in the domestic sphere. She is working, and remain burdened with domestic responsibilities such as raising children, taking care of the house, cooking, preparing family needs, and so on.

The issue of a double burden on women workers is still a problem that is difficult to solve. Many experts have studied it from various points of view. Research by Sungkawati and Ratnawati (2015), for example, explains the link between modernity and women's a double burden. Apart from their role as housewives, women also need to adjust their roles as housewives and breadwinners due to the guidance of the times. This study also explains that the female workforce in modern times has more potential than men in the industrial sector in the formation of the household economy.

Meanwhile, Thung Ju Lan (2015), in his writing entitled Women and Modernization try to understand the changes that occur in women about modernization. In essence, both women in rural areas and women in urban areas 
are affected by modernization which changes their values. However, modernization did not bring about gender equality it promised, even socio-cultural inequalities were seen between women in rural areas and women in urban areas. Shifting values and changing gender relations do not help solve the problems of women, especially poor rural women. Therefore, in this paper, Lan proposes a review of state policies, which are currently too focused on increasing the role of women in development, so that they pay more attention to the role of women in the family as pillars of progress in society and the nation.

Syaifuddin Zuhdi (2018), in his article entitled Membincang Peran Ganda Perempuan dalam Masyarakat Industri, concludes that the natural nature of a woman is to work in the domestic sphere, but this does not rule out a shift in the role of women in society, especially about the role which has economic value, so that in the initial conditions working in the domestic sphere becomes the public domain. This shift is the impact of women's participation in an economic role so that it becomes an industrial society based on money-oriented, this participation results in family conditions and social community relations, if they can respond to and overcome problems that arise properly, then the effect of work participation it becomes good, and vice versa, if they cannot respond wisely, it will damage family and social relations.

A discussion about a double burden experienced by women was also written by Dwi Edi Wibowo (2016) with the title Peran Ganda Perempuan dan Kesetaraan Gender. For Wibowo, the discourse on femininity, which mostly revolves around the assumption of dichotomous separation between the domestic and public spheres, turns out to be a lot of confusion. This happens not only to traditional perceptions of the sexual division of labor but also to perceptions of women's a double burden. It all happens because the domestic and public areas are seen as two sides that are diametrically separated. If it is seen as two interconnected points, of course, such a dichotomy will not arise. Between domestic and public is like between home and the world. Homes are also part of the world. A man and a woman can't discover the meaning of their presence in the world until they discover the meaning of their presence at home. Home and world are not two names of two types of space. The most important thing for a man or woman is not to know where to spend the most time and concentration. However, it is precisely the extent to which both of them have a high dedication to the house and everything in it and further extend that service beyond the physical confines of their house, to worldwide service. Both 
must have an unavoidable attachment to their home on the one hand and also have a universal consciousness on the other. Women and men are not two completely different creatures, but also not the same. Women and men are oneself even though they occupy two different bodies. They are created not to oppress and dominate each other but to need each other so that responsibility, maturity, and self-calmness can be achieved.

From the studies above, we can see that the discourse on women and their roles in the public sphere has become an important issue. Women as individuals have succeeded in changing society's view of themselves. Through the agency that exists in her, she has succeeded in increasing individual capacities by empowering herself in a sphere that he had never previously occupied. Women have dominance, power, or the ability to make choices and consider the consequences (Kabeer, 2005). However, many studies on women and their roles in the public sphere tend to only explain the double role and double burden of women, as well as their role in fulfilling the family economy, without seeing or even involving the traditions inherent in women as part of the dialectical process.

In this modern era, women live "in the world" in a different sense from the previous era. Every woman still lives and cares for her local life (tradition), but in a different context and space and time (modern). The transformation of place, space, and time that is more modern doesn't just eliminate the behavior or life of women who rely on previous traditions. This condition has the opportunity to create disharmony in women's lives if only they are not able to re-interpret the traditions inherent in their bodies. Re-interpreting traditions and values of konco wingking is a process of identifying and re-shaping women's identity during today's modernization era. This is at the same time an attempt for women to get out of the hegemony of the patriarchal tradition they are experiencing. As is done by women working in Paciran. As is done by women workers nguplik in Paciran.

Nguplik is a job done by individuals and or a group of women. Nguplik usually consists of eight to eleven members who work to separate the shell or skin of the ripe crab from the meat to be sold and processed into food and cosmetics.

Nguplik has become a real battle arena for women in Paciran to get out of their hegemony of the patriarchal tradition. Nguplik, apart from being the most important economic dimension for women in Paciran, has also become a strategy to build women's social relations in Paciran as an effort to reduce the hegemony of the patriarchal culture that surrounds them. 
Through nguplik, women in Paciran try to unravel their position through a process of shifting the subject and at the same time realizing themselves as objects of a tradition and culture. This means that konco wingking as a tradition, culture, and even women's identity, is not constant, static, but continues to move or will never end. In this case, konco wingking as a tradition is influenced by historical dimensions (there are space and time), so that the construction of konco wingking itself takes place in a dynamic process. The meaning of konco wingking is also considered part of the agent's attitude and response to the developing dynamics, namely konco wingking that are dynamic, contextual, and represent the identity of women in the structure of society. In other words, there is a re-meaning of tradition with a new function that goes on in history.

The efforts of women in Paciran to redefinition this tradition are what I call tradition moderation. The moderation of this tradition is a dialogical effort (adjustment of traditions) between traditions in their old context and the present context carried out by Paciran women to find a common ground between the two that allows the emergence of traditional practices that are different from their old forms but still originate in previous traditions. For example, in the modern world, konco wingking can no longer be interpreted as a "place of origin" with its domestic role; macak, masak, manak as static "memory traces", represented by the position of women always being in the house. Rather, it must be interpreted as a "place of return", the tradition that gives women a foothold in their view of social reality; community and family.

In this modern era, konco wingking can be activated through various actions, one of which is work, in this case nguplik. In the end, the konco wingking presentation was not only seen from the position and role of women within the house but also the position and role of women in the public sphere. Nguplik is an attempt by women to connect the public and domestic sphere, between home and current social realities.

This research was conducted a women's workes nguplik, which was located in Paciran Village. The researcher used a purposive sampling technique. Each research subject was selected by taking into account different characters, for example from the level of education, age, and place of residence. To support the research data, the researcher also interviewed the husbands of women working in the nguplik.

This study used a qualitative method with a case study approach. The case study approach is suited to answer questions that require the researcher to go deeper and obtain answers to research questions by exploring and elaborating (Rahardjo, 2017). 
In this study, the researcher conducted the first step by collecting data through literature reviews, observations, and in-depth interviews. Next, the researcher conducted data analysis and data interpretation using the cultural sociology theory. Data interpretation was made by narrating the finding data into a patterned story.

Data analysis was performed using four steps - first, data collection, which was done through observation, interviews, and literature studies process. Second, the data are sorted according to the research's needs. Third, presenting and analyzing data based on research questions. Fourth, draw the conclude.

\section{Leaving the House: An Effort to Reinterpret Tradition}

The strong hegemony of tradition and patriarchal culture which places women in the domestic sphere, in fact, does not discourage women in Paciran from leaving the house. This is similar to what is done by women working in Paciran. In their position as housewives with various domestic activities, they can still work well.

Changes in the role of women in Paciran, from domestic to public, are influenced by their awareness of the changing times that are starting to open up, are fast-paced, and the price of necessities continues to increase. The change was welcomed by women in Paciran as an opportunity to be able to help the household economy. Which ended in the shift in the meaning and role of konco wingking in Paciran. Mrs. SV, a housewife, and worker revealed that the practice of konco wingking in the modern era like today can no longer be interpreted only at home. The situation and conditions compelled to change it,

"Kebutuhane tambah akeh mas, opo-opo saiki larang nek jogokno olehe bojo yo ora cukup seulan. Bayaran sekolahe anak, beras, gas, listrik, durung keperluan liya-liyane. Makane aku melu kerjo pisan, tapi ora berarti aku lali tugase dadi bojo."

(The need is more and more, the need is increasing if only relying on the husband's salary is not enough for a month. School fees for children, rice, gas, electricity, not for other purposes. That's why I come to work, but that doesn't mean I forget my duty to be a wife).

The same thing was conveyed by Mrs. RD about the reason she chose to "leave the house". In line with Mrs. SV, Mrs. RD considers that it is her economic needs that force her to work, 
"Anakku loro mas, wes sekolah karo-karone. Siji kuliah, seng loro SMA. Butuh biaya mas, opo maneh saiki opo-opo larang kabeh. Yo gelem gak gelem melu mergawe, tapi yo tetep aku mengurusi anak, bojo. Ora berarti aku lali tugase dadi bojo"

(I have two children, both of them are already in school. The first is college, the second is high school. It takes money, especially now everything is expensive. Even though I work, I don't forget my duty as a wife).

Therefore, as a tradition that is continuously reproduced by women, konco wingking can come into existence by the underlying reality. This means that the form of konco wingking does not only exist in the domestic sphere, or the household sphere is just as friends behind; macak, masak, manak, but it can take different forms according to the social conditions of the household that underlie it. In Paciran, for example, the form of konco wingking can be the participation of women in improving the household economy.

Furthermore, the practice of konco wingking in Paciran village is ultimately sak apike (supposed) for women. The use or implementation of konco wingking is not an obligation that must be done by women at all times. This characteristic implies that all actions are carried out by looking at the situation. This allows everyone, including women to interpret konco wingking according to existing conditions.

This is like what was conveyed by mbah Nab, "Zamane wes bedo, seje karo biyen. Saiki wong wedok yo kudu iso ndelok gon. Kapan wayae nek omah, kapan wayae mergawe. Wes ora iso nek omah terus, tapi yo ora apik nek mergawe terus. Wong wedok kudu iso delok seng apike piye kanggo awake karo keluargane." (The times have changed, different from the past. Now women have to be able to see the situation. When is the time at home, when is the time to work. I can't stay home anymore, but it's not good to keep working. Women must be able to see the best for themselves and their families).

In this context it is necessary to underline that konco wingking is also seen as a "place of return" in the balance in the household, it essentially underlies the lives of women in Paciran in all their activities. As stated by Mrs. AF below, "Masio wes kerjo mas, yo tetep ngurusi omah, ora oleh lali karo anak bojo." (Even though you have worked, you still take care of the house, you can't forget your children and husband).

From the interview excerpt above, we can see that the emergence of the meaning of konco wingking as a foothold in household balance is also a form of women's 
positioning in Paciran. This presents an open choice of activities that determine the position of women, both inside and outside the home, the domestic sphere, or the public sphere. Women have the possibility to be outside as well as inside, but women must be able to determine their priorities to ensure which sphere to occupy and at what time she must be in that sphere.

The involvement of women in Paciran in the public sphere, such as nguplik, proves that domestic domination in the konco wingking tradition is no longer the only main axis in interpreting it. The high level of women's participation in the public sphere is contrary to the general perception of women. Women are considered as a "behind" society group, in fact, women can come forward well (Raharjo, 1995; Fakih, 2013; Newberry 2013; Permanadeli, 2015).

Working (nguplik) has provided the widest possible opportunity for women to walk their own way of life. Basically, women who have worked have good enough autonomy to make all decisions related to themselves.

Even though the chosen job has a flexible period of time, nguplik has changed many habits, even norms that generally apply in Paciran. This is where a lot of women's domestic work, such as cooking, sweeping, and even raising children, have also begun to be done by their husbands. An informant, Mr. ZD, the husband of Mrs. RD conveyed, "Nek bojoku durung muleh, yo biasane aku adang dewe." (If my wife hasn't come home, I usually cook it myself). Thus, the entry of women into the world of work has shifted the meaning and role of konco wingking that exist in the Paciran community, not only in domestic matters, such as macak, masak, manak, but also mergawe (work).

\section{Double Burden as a New Tradition}

The freedom to enter women into the world of work is like nguplik in Paciran, but in fact, it does not just free women from household affairs. This is due to the patriarchal traditions and culture that place women as the other.

This "the other" is what makes women always positioned in a "different place" from men. Being the other, bring up the separation between his selves with another self (male) in any case. This separation is like a maze that traps women into compartmentalized perceptions and justifications. This separation unfortunately has led to divisions, boundaries, norms, and subordination of women to men, such as the concepts: production-reproduction, public-domestic, and nature-culture 
(Newberry, 2013; Ortner, 1974; Rosaldo, 1974). This division then manifests into rights and obligations that must be borne and assigned to each of them, resulting in social stratification to subordination between men and women and indirectly reducing the role of women (Zayyadi: 2012).

That is why, even though women have worked, they will still be connoted as a homemaker who is considered unable to contribute actively outside the home so that their role is no more than just a compliment. We can see how women are actively involved on all fronts. Starting from the economic, social, political to religious fields. All lines have been able to rely on women as productive and reliable human resources. Even so, after all, many things still shackle women in their activities in the productive sphere. Many strategic positions are difficult for women to access. Women are considered unable to lead in work because they are considered to relying on emotions and feelings, making it difficult for them to make good and wise decisions. Women are also considered weak and underpowered in hard jobs that rely on muscles. The strong influence of these cultural values on women in the end also underlies the emergence of a double burden for working women.

The dual role is referred to as the concept of cultural dualism, namely the concept of the domestic sphere and the public sphere (Michelle, 1974). A double burden is women's participation regarding the role of tradition and efforts to transition the traditions by women. Tradition or domestic roles include the role of women as wives, mothers, and household managers. Meanwhile, the tradition transition efforts include the notion of women as workers, members of society, and human development. In the tradition transition effort, women as workers are actively involved in economic activities (earning a living) in various activities according to their skills and education as well as available jobs.

The double burden is still a problem for working women today. Likewise with female workers nguplik in Paciran. They must be able to divide their time between the domestic sphere and the public sphere. As conveyed by Mrs. SV,

"Nek isuk biasane aku tangi disikan, jam limo isuk. Terus neng pasar, belanjo gawe sarapan. Mari ngono masak, nyetrikakno seragame anak gawe sekolah. Nyambi masak, aku yo ngedusi anak. Mari ngono ngeter anak sekolah sampek jam songo, terus budal neng gudang, nguplik."

(Every morning I usually wake up first, at five in the morning. After that go to the market, shop for breakfast. After that cook, iron the child's school uniform. 
After that, I washed the child. After that, take the school children until nine oclock, after that go to work, nguplik).

However, for women workers nguplik in Paciran, the double burden is not the reason for them not to leave the home. The double burden is a consequence of being aware of changes in practice that are happening at this time, which he chooses himself.

They take this consequence because they have not been able to completely abandon their efforts to get out of the traditions and cultures that have been taking existence. The woman working at the nguplik in Paciran revealed that if something cannot be obtained entirely does not mean leaving it as a whole. This means that the positioning of women is important, not to erase tradition, but a strategy to reinterpret tradition.

With this understanding, a double burden is not a burden for women working in the community. Rather, it is the strategy of women in Paciran to be able to leave the home and be able to compete in the public sphere. This is like what was conveyed by Mrs. SV,

"Zaman saiki wong wedok kudu giat, ora mung terimo opo anane, ora mung dadi konco wingking, tapi yo kudu iso dadi konco urip. Orang mung nadah jaluk bojo, tapi yo kudu iso bantu bojo bareng-bareng."

(Now, women must be active, not only accepting what they are, not only being a konco wingking but also a konco urip. Not only waiting for your partner, but you have to help your husband together).

Seeing the opinion of the informant above, that women should not just stand by, and surrender to being a konco wingking. He should be able to be a konco urip (soul mate) that can contribute to the family. Konco urip also signifies egalitarian nature, the parallels of life between men and women. Konco urip is not just "being a wife", it is a woman who controls and manages all activities in the household. But also women who can provide life and maintain the sustainability of the household.

Within this framework, konco urip also provides social awareness about husband and wife who do have an equal relationship, which cannot be differentiated and separated. Husband and wife show the similarity of the relationship between household and social space where the two are not separated from each other and are always related to creating a better situation. That is how the konco urip sits the 
husband and wife in the same place, through the household space to a wider social space (Maulana, 2020).

Therefore, the double burden that is still experienced by women workers nguplik in Paciran, is not without value. It is one of the efforts or strategies to survive women in a public sphere that has been dominated by men.

In the end, this new tradition also generated a new response for women in Paciran regarding the situation they were experiencing. In this case, women in Paciran must be able to share their time as housewives with their status as mother workers.

\section{Nguplik: A Form of Tradition Moderation}

The presence of women in the public sphere marked by their entry into the world of work has provided a new perspective on the meaning of konco wingking which is not only simplified through macak, masak, manak, but also mergawe (work). This change in roles can be seen as a result of women's efforts to minimize the domination of patriarchal culture and traditions.

Through this new practice, konco wingking is reproduced through public activities, one of which is nguplik. The large number of women in Paciran who duplicate is also a sign that they exist and are accepted as part of a community that also deserves to be taken into account in the household economy, country, and even the world. They also began to prove the view that women can move from place (house) to another place (public) without leaving their place of origin (community) as their identity.

Nguplik is a picture of women's awareness of their position that has "moved" from the ideal norms of konco Wingking. However, "moving from the place" also does not mean changing oneself from the "place" of origin (society). The relocation of women's places implements that the konco wingking can be reproduced or even opposed to becoming a new practice that does not only place women as the ones behind (domestic).

Understand and re-practice konco wingking as an effort to minimize the domination of patriarchal culture and traditions, placing Paciran women in a position that is no longer "marginalized" through domestic roles. The konco Wingking that was presented was a new face, namely mergawe. They change the realm that was previously positioned in the domestic sphere to become the public sphere. 
Under such conditions a transition the tradition takes place. Traditions are revisited, dialogues, and practiced in their new conscious forms. Women as agents through their conscious thought review thoroughly the tradition (konco wingking) which is exposed to a new context. The tradition that the agent has successfully created with its new context is ultimately manifested in new actions.

Agents to borrow Bourdieu's definition, are individuals or actors who can direct and or inhibit practice. Bourdieu considers agents as individuals capable of constructing dialectics with structures. The dialectic then constructs social reality as social practices (Jenkis, 1992; Rizer and Goodman, 2010), while according to Giddens, agents are individuals who have a lot of knowledge (knowledgeable agent) and the ability to understand their own actions. They are not mere cultural strata or supporters of social relations, but they are skilled actors who have a great deal of knowledge about the world they are in (Thompson, 1984: 240-241).

As a woman agent in Paciran, she has succeeded in changing the view of society about herself, which is not only considered a passive individual with all the acceptance she receives, about the position, status and role. Rather, he is an active individual who can make changes to his position, status, and role in society. This can be seen from the changing roles that have occurred in Paciran. Women do not only play a role in the home but also work (play a role outside the home). Mrs. RD revealed,

"Zaman saiki wong wedok ora dolok nek omah tok mas. Akeh seng podo kerjo. Bandani keluarga ngrewangi bojo. Mangkane penggaweane wong wedok saiki ora mung nek pawon tok mas, tapi yo nek jobo barang."

(Nowadays, women don't just stay in the house. Many are already working. Support the family to help the husband. That's why women's activities now are not only in the kitchen but also outside as well).

Paciran women as agents have the capacity to produce the right expressions or decisions in certain situations with their actions. It also involves continuous reflexivity in action, which is understood as the potential to act so that the agent as an individual always has an idea about the conditions of his social life (Bourdieu, 1977). In this modern era, agents (Paciran women) have to carry out various strategies in their actions to fight out their stereotypes and marginalities.

Thus every agent has a way or strategy to fight out of their stereotypes and marginalities. Every agent has a strategy to get what he wants; although limited by his status and position as a konco wingking. 
However, for women in Paciran, konco wingking as a tradition is not in a static position, it is dynamic, always by the changing times, therefore konco wingking is always in a condition that is contested by themselves. They identify themselves as the most understanding and practicing konco wingking in everyday life. That is why the moderation of the konco wingking tradition is carried out by women in Paciran. The moderation of the konco wingking tradition is part of the efforts of women in Paciran to keep themselves in the right position, even though they are in a different space or era (public or modern). The moderation of tradition is an attempt by Paciran women to explain the cultural logic of Javanese women in seeing themselves and society (the other) in the midst of social life.

Tradition moderation puts tradition and modernization in an equal position. Tradition and modernization are related to one another. The agent, through his conscious thought, then moderates the tradition by reviewing the existing values (in the tradition) and then adjusting the existing values to new conditions that are different (modern). She lives the old values that exist in the tradition and simultaneously carries out the new values that are found from the results of modernization simultaneously in a new (modern) context, and in the end, it becomes a new tradition for women (Maulana, 2020).

This moderation process will not work if the agent fails to moderate the structures that allow for mutual opposition (old-new; traditional-modern; internalexternal) (Bourdieu, 1977). Tradition moderation is an attempt to be able to find a middle ground (balance) from the intersection of old values (produced by tradition) and new values (produced by modernization) (Misrawi, 2010; Hanafi, 2013; Kamali, 2015; Maulana, 2020).

Konco wingking as a tradition is a set of social relations that has endowed Paciran women (agents) with -capital- power, status, and resources. Individuals occupy a position determined by the capital they have, and the relationship between positions in one domain will reflect the relationship between positions and other domains (Bourdieu, 1977). The objective network of relations between these positions encourages and orientates the strategies that agents use in various ways or actions in maintaining or changing their positions.

This is where the dialogical role of women is needed as an agent between the internal structure and the external structure which encourages moderation of the konco wingking tradition as an inseparable part of women as individuals (self) and in women as part of society (society). 
The moderation of the konco wingking tradition is once again an attempt by women in Paciran to minimize the domination of patriarchal culture and traditions. The production and reproduction of konco wingking as an effort to form new values is the re-formation of konco wingking in a new contextual form. Women in Paciran try to balance the konco wingking values that come from the past with the context of the modern era that gives women the freedom to leave the house.

The capacity of women in Paciran as agents thus does not stop as passive users of Javanese women's values, but actively criticizes them and dialogues them as new values to show their position in the public sphere. In this context, nguplik is a form of moderation of tradition, the result of the dialectic of agents in dynamics and change, and understanding that traditions are not static and are able to interact with the social environment as a social reality and give birth to the knowledge that is different from the past.

\section{Conclusion}

Domestic activity is two words that cannot be easily separated from the female body even though the world changes so fastly. The freedom of women entering the world of work today is also not able to eliminate these two words from themselves completely. This is due to the traditions and culture that place women as others.

This otherness makes women always positioned in a "different place" from men. Being another creates a separation between the female self and the other-self (male) in any case. This separation is like a maze that traps women into compartmentalized perceptions and justifications. This separation has unfortunately led to divisions, roles, norms, and traditions that often subordinate women to men (Newberry, 2013; Ortner, 1974; Rosaldo, 1974).

That is why, even though women have worked, they will still be connoted as homemakers who are considered unable to contribute actively outside the home so that their role is no more than just a complement. We can see how women are actively involved on all fronts. Starting from the economic, social, political to religious fields. All lines have been able to rely on women as productive and reliable human resources. Even so, after all, many things still shackle women in their activities in the productive sphere. Many strategic positions are difficult for women to access. Women are considered unable to lead in work because they are considered to relying on emotions and feelings, making it difficult for them to make decisions 
properly and wisely. Women are also considered weak and underpowered in hard jobs that rely on muscles.

The strong influence of these cultural and traditional values on women ultimately also underlies the boundaries of job selection for women. In fact, on the other hand, the changing times that are increasingly modern provide opportunities for freedom to choose work.

Women are faced with a dilemma between tradition and modernization. They will be deemed to have uprooted their traditions if they choose to work. On the other hand, the existing basic needs cannot be met only from the husband's income. However, women in Paciran were able to get out of this dilemma by successfully moderating the konco wingking tradition by changing the meaning and role of the tradition. They succeeded in changing the meaning and view of the konco wingking tradition which had been considered a "place of origin" with its domestic role; macak, masak, manak as static traditions, represented by the position of women always being in the house. However, it is also a "place of return" the tradition that becomes the foothold of women's life in viewing social reality; community, and family.

In moderation of the konco wingking tradition, the struggle for the identity of Paciran women is reflected. Even though it starts from an unbalanced position in the internal structure which has implications for the external structure, it doesn't necessarily make Paciran women worse off, in fact, with the spirit of konco wingking it becomes a trigger and trigger to rise so that its existence is recognized.

Through efforts to parse his position through a process of shuttling the subject at the same time realizing himself as the object of a tradition and culture. Women in Paciran have succeeded in changing the view of society, that not all women who work will definitely leave tradition. Traditional moderation has succeeded in positioning women in a society, where they must be, in the domestic or public sphere.

The production and reproduction of konco wingking in new knowledge which is full of cultural values in the traditions of the people are considered as the construction of historical awareness that they produce in open space to present in the form of new roles. Thus it will be understood the process of subject-object shuttling carried out by Paciran women to reaffirm their identity in the midst of tradition representations that have so far considered marginalized women. This process is not only carried out through ideas but also various actions, as well as the emergence of an awareness of the existence of Paciran women. 
The moderation of the konco wingking tradition has encouraged Paciran women not to just stay at home, but to move and be respected for their existence. What Paciran women have successfully done with their ability to use cultural symbols can be said to be the success of their efforts in seeing themselves (self) and society (the other) in the middle of social life.

Now, Paciran women are considered to have succeeded in leaving the house, even starting to play roles that have been controlled by men, namely mergawe. They have also succeeded in cultivating the spirit of a sense of collectivism through the success of utilizing symbolic and cultural capital. They have changed the current constellation of agent-structure relations in social space. As a tradition to be negotiated/renegotiated, konco wingking becomes dynamic, and the work of agents in this study is an achievement so that konco wingking is interpreted as more rational and proportional to women today.

As a manifestation of the moderation of tradition, nguplik shows the real efforts made by women in Paciran, that women are not only capable of being in the domestic space, but also able to work well in the public space. Nguplik has also become a space to build social relations for women in Paciran who seek to minimize the hegemony of the patriarchal tradition that has existed in Paciran society. Also, nguplik has become a real battle arena for women in Paciran to meet household needs. Now, nguplik has become the most important economic dimension for people in Paciran.

\section{References}

Abdullah, Irwan. (1997). Sangkan Paran Gender. Yogyakarta: Pustaka pelajar.

Ahdiah, Indah, (2013). Peran-Peran Perempuan Dalam Masyarakat. Jurnal Academica, 05(2), 85-92. http://jurnal.untad.ac.id/jurnal/index.php/ academica/article/view/2247/1450

Bainar. (1998). Wacana Wanita dalam Keindonesiaan dan Kemodernan. Yogyakarta: Pustaka Cidesindo.

Blackwood, Evelyn. (2000). Not Your Average Housewives, on Women and Work in Indonesia. Edited by Michele Ford and Lyn Parker. New York: Routledge.

Bourdieu, Pierre. (1977). Outline of A Theory of Practice. Cambridge University Press. 
Bourdieu, Pierre. (1998). Practical Reason on The Theory of Action. Cambridge: Polity Press.

Dewi, Putu Martini. (2012). Partisipasi Tenaga Kerja Perempuan dalam Meningkatkan Pendapatan Keluarga. Jurnal Ekonomi Kuantitatif Terapan, 5(2), 119-124. https://ojs.unud.ac.id/index.php/jekt/article/view/1906/1360

Faiz Maulana, Moh. (2020). Moderasi Tradisi Konco Wingking: Upaya Melepaskan Dilema. Jurnal Harkat, 16(1), 11-26. https://doi.org/10.15408/harkat. v16i1.15609

Fakih, Mansour. (2013). Analisis Gender \& Transformasi Sosial. Yogyakarta: Pustaka Pelajar.

Geertz, Hilderd. (1961). The Javanese Family. New York: Free Press of Glencoe.

Giddens, Anthony. (1992). Modernity and Self Identity. Cambridge: Polity Press

Giddens, Anthony. (2005). Konsekuensi-Konsekuensi Modernitas. Yogyakarta: Kreasi Wacana.

Hall, Stuart, \& Paul Du Gay. (1996). Questions of Cultural Identity. London: Sage Publications.

Hall, Stuart. (1991). Culture, Globalization and The World-System: Contempory Conditions for The Representation of Identity. Edited by Anthony D. King. London: MacMillan Education Ltd.

Hanafi, Muchlis M. (2013). Moderasi Islam, Jakarta: IAA-PSQ.

Handayani, Christina S., \& Ardhian Novianto. (2011). Kuasa Wanita Jawa. Yogyakarta: LKiS

Harker, Richard, Cheelan Mahar, \& Chris Wilkes. (ed). (2009). (Habitus x Modal) + Ranah $=$ Praktik. Yogyakarta: Jalasutra.

Hashim Kamali, Mohammad. (2015). The Middle Path of Moderation in Islam: The Quranic Principle of Wasatiyyah. New York: Oxford University Press.

Hasibuan, Liliana. (2017). Antara Emansipasi Dan Peran Ganda Perempuan (Analisa Fakta Sosial Terhadap Kasus Ketimpangan Gender), Jurnal Hikmah, 11(2), 362-379 https://doi.org/10.24952/hik.v11i2.752

Hidayati, Nurul. (2015). Beban Ganda Perempuan Bekerja (Antara Domestik Dan Publik). Jurnal Muwazah, 7(2), 108-119, http://e-journal.iainpekalongan. ac.id/index.php/Muwazah/article/view/516 
Hobsbawm, Eric, \& Terence Ranger. (1992). The Invention of Tradition. Cambrige University Press.

Holzner, B., \& Saptari, R. (1997). Perempuan Kerja dan Perubahan Sosial. Jakarta: PT Pustaka Utama Grafiti.

Inawati, Asti. (2014). Peran Perempuan dalam Mempertahankan Kebudayaan Jawa Dan Kearifan Lokal, Musâwa, 13(2), 195-206. https://doi.org/10.14421/ musawa.2014.132.195-206

Jenkis, Richard. (1992). Pierre Bourdieu. London: Routledge

Kabeer, Naila.(2005). Gender Equality and Women's Empowerment: A Critical Analysis Of The Third Millenium Development Goals. Gender and Development, 13(3), 13-24. https://doi.org/10.1080/13552070512331332273

Lan, Thung Ju. (2015). Women and Modernization. Jurnal Masyarakat dan Budaya, 17(1), 17-28. https://doi.org/10.14203/jmb.v17i1.118

Mahmuda, Nanik. (2015). Perempuan dalam Tantangan Modernitas. Jurnal AnNisa', 8(1), 1-16. http://annisa.iain-jember.ac.id/index.php/annisa/article/ view/77

Misrawi, Zuhairi. (2010). Pandangan Muslim Moderat, Jakarta: Kompas.

Morgan, D.H.J., (1975). Social Theory and The Family. London: Routledge \& Kegan Paul Ltd.

Ortner, S.B. 1974. Is female to male as nature is to culture? in Women, Culture, and Society, Edited by M. Rosaldo \& L. Lamphere. Standford: Standford University Press.

Permanadeli, Risa. (2015). Dadi Wong Wadon Representasi Sosial Perempuan Jawa di Era Modern. Yogyakarta: Pustaka Ifada.

Rahardjo, M. (2017). Studi kasus dalam penelitian kualitatif konsep dan prosedurnya. http://repository.uin-malang.ac.id/1104/1/Studi-kasus-dalam-penelitiankualitatif.pdf.

Raharjo, Yulfira. 1995. Gender dan Pembangunan. Jakarta: Puslitbang Kependudukan dan Ketenagakerjaan, LIPI (PPT-LIPI).

Ramadhani, Ninin. (2016) Implikasi Peran Ganda Perempuan Dalam Kehidupan Keluarga Dan Lingkungan Masyarakat. Jurnal Sosietas, 6(2), https://doi. org/10.17509/sosietas.v6i2.4245 
Ritzer, George, \& Douglas J. Goodman. (2008). Teori Sosiologi Modern. Jakarta: Kencana Prenada Media Group.

Rosaldo, M.Z. 1974. Women, Culture, and Society: A Theoretical Overview. in Women, Culture, and Society, Edited by M. Rosaldo \& L. Lamphere. Standford: Standford University Press.

Sukri, Sri Suhardjanti \& Ridin Sofwan. 2001. Perempuan dan Seksualitas dalam Bahasa Jawa. Yogyakarta: Gama Media.

Sungkawati, E., \& Ratnawati. 2015. Motivasi Wanita Bekerja dalam Rangka Meningkatkan Perannya di Bidang Ekonomi. Prosiding. Fakultas Ekonomi dan Bisnis Universitas Wisuwardhana Malang. 329-336, https://psp-kumkm. lppm.uns.ac.id/wp-content/uploads/sites/21/2016/01/endang-sungkawatiprosiding-sme-s-combinedpdf_1

Susilantini, Endah. (2006). Peran Ganda Wanita Indonesia. Jurnal Jantra (Sejarah dan Budaya). 2(1), 99-105. http://repositori.kemdikbud.go.id/id/eprint/5138

Thompson, John. (1984). Studies in The Theory of Ideology. Cambridge: Polity Press Wibowo, Dwi Edi. (2011). Peran Ganda Perempuan dan Kesetaraan Gender. Jurnal Muwazah, 3(1), 356-364. http://e-journal.iainpekalongan.ac.id/index.php/ Muwazah/article/view/6

Wijaya, Angga (ed). (2017). Tulang Punggung; Relasi Industri Terhadap Buruh Perempuan. Jakarta: Dewan Kesenian Jakarta (DKJ)

Zayyadi, A. (2012). Perempuan Bekerja (Tinjauan Gender Equality Dalam Peran Keluarga). Yinyang: Jurnal Studi Islam Gender dan Anak, 7(2), 40-54. http:// ejournal.iainpurwokerto.ac.id/index.php/yinyang/article/view/1167

Zuhdi, Syaifudin. (2018). Membincang Peran Ganda Perempuan Dalam Masyarakat Industri. Jurnal Jurisprudence, 8(2), 81-86 